\title{
ANALISIS FAKTOR PENYEBAB BERKURANGNYA UPACARA PERNIKAHAN SHINZEN KEKKON DI JEPANG, KHUSUSNYA DAERAH KANSAI
}

\author{
Nalti Novianti ${ }^{1}$; Edi Dianto ${ }^{2}$ \\ ${ }^{1,2}$ Japanese Department, Faculty of Language and Culture, Bina Nusantara University, \\ Jl. Kemanggisan Ilir III No. 45, Kemanggisan/Palmerah, Jakarta Barat 11480, Naltin@binus.edu
}

\begin{abstract}
Modernization era has left some particular part on traditional ceremony because it is unpractice reason, like take too much time. It also happens on the wedding ceremony wich has many customs and tradition. One of Japanese wedding tradition is shinzen kekkon, this wedding ceremony is held for Shinto's beliver. Article explores how is Japanese young generation opinion about their wedding ceremony, besides their knowledge about every part of the ceremony. On conclusion part, it is known that Japanese tradition has spirant in its process.
\end{abstract}

Keywords: traditional wedding, Japanese wedding, young culture, shinzen kekkon

\begin{abstract}
ABSTRAK
Modernisasi mengakibatkan ditinggalkannya cara tradisional yang dianggap tidak praktis dan memakan waktu. Hal itu tampak juga pada tata cara melangsungkan pernikahan yang penuh dengan berbagai macam tata adat yang perlu dilaksanakan agar terpenuhinya kesahan suatu perkawinan. Upacara pernikahan yang dianggap sebagai tradisional Jepang adalah upacara pernikahan ala Shinto, yang disebut shinzen kekkon. Artikel menjelaskan sejauh mana kaum muda Jepang masih tertarik untuk melaksanakan upacara perkawinan tradisional. Selain itu, ingin diketahui apakah para responden masih mengetahui makna setiap ritual yang ada di dalam upacara Shinzen Kekkon. Akhirnya dapat disimpulkan, kebudayaan Jepang telah mengalami pergesaran.
\end{abstract}

Kata kunci: perkawinan tradisional, perkawinan Jepang, kaum muda Jepang, shinzen kekkon 


\section{PENDAHULUAN}

Dalam kehidupan, manusia selalu mengalami siklus kehidupan yaitu: kelahiran, masa anakanak, remaja, dewasa, orang tua, dan kematian. Masyarakat Jepang percaya ada empat siklus yang harus dilalui dalam kehidupannya, yaitu seiiku kaitei (tahap pertumbuhan), seijin kaitei (tahap dewasa), shiryoo kaite (tahap kematian) dan sorei kaitei (tahap arwah).

Dalam tahap pertumbuhan, seorang individu akan mengalami perkembangan fisik. Ia akan tumbuh dari bayi sampai dewasa. Di Jepang masa-masa pertumbuhan mulai dari lahir hingga dewasa ini dibagi menjadi yoonen jidai (usia 1-6 tahun), shoonen jidai (usia 6-15 tahun), kookoosei to daigaku nyuushi (usia 16-18 tahun), daigaku jidai (usia 18-22 tahun). Setelah memasuki umur 22 tahun umumnya mereka baru akan mulai memikirkan tentang perkawinan.

Perkawinan dalam Bahasa Jepang disebut dengan istilah kekkon ( 結婚 ) atau kon in ( 婚姻 ). Istilah kekkon terdiri dari dua karakter Kanji yaitu ketsu ( 結 ) yang berarti ikatan dan kon ( 婚) yang berarti perkawinan. Sedangkan kon in terdiri dari kon ( 婚) yang berarti perkawinan dan in ( 姻 ) juga berarti perkawinan. Perkawinan secara harafiah berarti penyatuan seksual makhluk lain jenis.

Dalam penyelenggaraan satu perkawinan, diperlukan tatacara tertentu yang mengatur individu-individu melalui sistem, nilai-nilai, norma-norma dan aturan-aturan yang mengatur masyarakat sehubungan dengan perkawinan disebut pranata perkawinan.

Dalam masyarakat Jepang ada dua macam cara yang bisa ditempuh oleh seorang calon suami atau seorang calon istri dipilih dan menjalin ikatan perkawinan, yaitu berdasarkan miai (dipertemukan atau dalam konteks perkawinan memiliki pengertian dijodohkan) dan ren'ai (cinta). Perkawinan yang terjadi karena miai disebut miai kekkon, sedangkan karena ren ai disebut ren ai kekkon.

Upacara perkawinan yang ada di Jepang dapat dibedakan menjadi empat macam yaitu, kirisutokyoo kekkon shiki (キリスト教結婚式) yaitu upacara perkawinan berdasarkan agama Kristen. Butsuzen kekkonshiki (仏前結婚式) perkawinan berdasarakan agama Buddha, Hitomae kekkonshiki (人前結婚式) perkawinan di hadapan orang, dan shinzen kekkon (神前結婚式) perkawinan berdasarkan agama Shinto.

Shinzen kekkonshiki merupakan upacara perkawinan yang khas dari bangsa Jepang. Tata cara upacara perkawinan ini dilakukan oleh Pendeta Shinto yang akan memimpin upacara. Ia berdoa di depan altar, kemudian pengantin pria akan mengucapkan janji perkawinan (Jinjya Kyoushiki, 2004).

Sebagaimana telah diuraikan diatas, Jepang dikenal sebagai negara yang mempertahankan tradisi dan budaya. Salah satu tradisi budaya Jepang adalah sistem perkawinan tradisional Jepang yang disebut dengan shinzen kekkonshiki. Penulis ingin mengetahui apakah dewasa ini perkawinan asli Jepang berdasarkan kepercayaan Shinto masih diminati oleh pasangan yang belum menikah, dan punya rencana untuk menikah. Penulis membagikan angket pada 50 orang muda Jepang dalam batasan umur 20 sampai dengan 40 tahun di daerah Kansai.

Untuk data pendukung dan informasi yang diperlukan dalam pembuatan penelitian ini penulis menggunakan angket sebagai korpus. Untuk menganalisis korpus data melalui jawaban responden, penulis menggunakan metode deskriptif analistis yaitu cara kerja membahas suatu masalah dengan cara menata dan mengklasifikasikan data serta memberikan penjelasan analisis tentang keterangan yang terdapat pada data. 


\section{PEMBAHASAN}

Jumlah responden yang menjawab angket ada 50 orang, dengan 26 orang pria dan 24 orang wanita. Responden semua tinggal di daerah Kansai, atau daerah timur laut Jepang. Alasan pemilihan responden, adalah karena mereka tinggal di daerah perkotaan yang dekat pusat pemerintahan. Apabila penulis memilih yang tinggal di pedesaan, maka pilihan mereka adalah pernikahan yang sesuai dengan pilihan orang tua, dan tidak mereka sendiri yang menentukannya. Karena itu, pilihan penulis jatuh pada orang-orang muda di kota besar yang lebih independen. Adapun pertanyaan pertama hingga ketiga dari angket tersebut adalah Jenis kelamin, umur dan pekerjaan.

Sedangkan pertanyaan kedua adalah mengenai pasangan hidup, apakah mereka memilih orang Jepang atau memilih orang asing untuk partner hidupnya. Pertanyaan ini ditujukan untuk melihat apakah ada hubungan antara kebebasan berfikir yang mereka adopsi dari kebudayaam barat, yang mempengaruhi cara mereka memilih pasangan hidup. Diantara 50 responden ( 43 orang ) 86\% memilih untuk tetap menikah dengan orang Jepang, dan sisanya ( 4 orang ) 8\%, memilih untuk menikah dengan orang asing. Alasan mereka adalah karena menikah dengan orang asing akan menambah wawasan pengetahuan dan pengalaman hidup, yang menjadikan hidup mereka lebih variatif. Sedangkan ( 3 orang ) $6 \%$, lainnya merasa tidak keberatan untuk menikah dengan orang asing maupun orang Jepang. Menurut Fukutake ( 1988: 10 ) Jepang merupakan salah satu negara modern, ditandai dengan adanya perkembangan ekonomi yang pesat, industrialisasi dan urbanisasi yang mempengaruhi seluruh komunitas dan semua kelas dalam masyarakat. Akan tetapi, modernisasi tetap tidak mengubah pandangan hidup orang Jepang untuk tetap memilih orang Jepang sendiri sebagai pasangan hidupnya dalam perkawinan.

Untuk lebih memperjelas angka prosentasi pemilih dapat dilihat pada grafik di bawah ini.

Tabel 1 Pasangan Hidup Pilihan

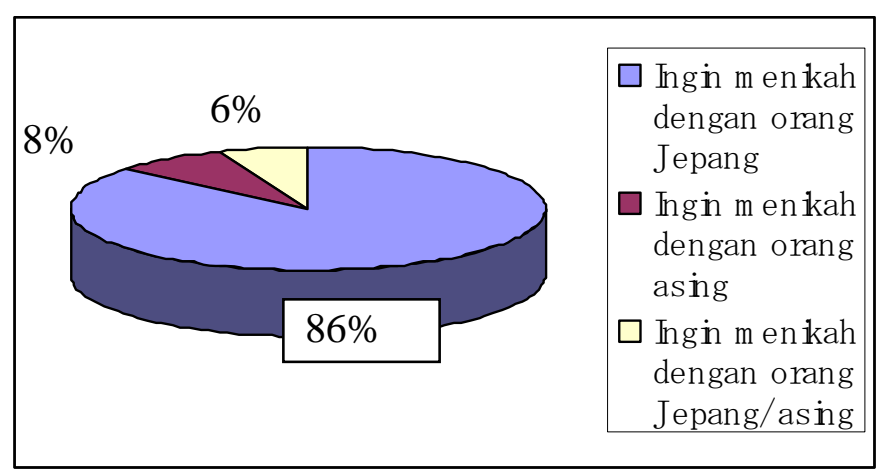

Menurut analisis penulis fenomena seperti ini terjadi karena faktor kendala bahasa. Orang Jepang tidak peduli dengan bahasa Inggris ataupun bahasa asing lainnya. Karena, walaupun bahasa Inggris merupakan bahasa Internasional dan merupakan bahasa pemersatu dunia, tidak menjadi alasan untuk bahasa tersebut ataupun bahasa asing lainnya menjadi bahasa kedua di Jepang, disebabkan karena orang Jepang sangat menjunjung bahasa mereka. Sebagai negara adikuasa kedua dibawah negara Amerika Serikat kebanyakan warga Jepang menganggap bahwa selain orang Amerika, semua orang di dunia ini adalah warga negara kelas dua dan mereka menjaga jarak terhadap warga negara kelas dua itu dalam hal apapun (Murakami, 1980). 
Untuk jawaban dari pertanyaan kedua yaitu "Jenis perkawinan apa yang mereka ingin mereka lakukan?”, sebagian besar menjawab ingin melakukan upacara perkawinan berdasarkan agama Kristen (Kirisutokyoo kekkonshiki) yaitu berjumlah 62\% (31orang). Yang memilih perkawinan (shinzhen kekkonshiki) berjumlah 18\% (9 Orang). Urutan ketiga yaitu perkawinan di hadapan orang (Hitomae kekkonshiki) yang berjumlah 16\% (8 Orang). Sedangkan sisanya yaitu 4\%( 2 orang) memilih jenis perkawinan perkawinan berdasarkan agama Buddha (Butsuzen kekkonshiki) .

Tabel 2 Pemilihan Cara Menikah

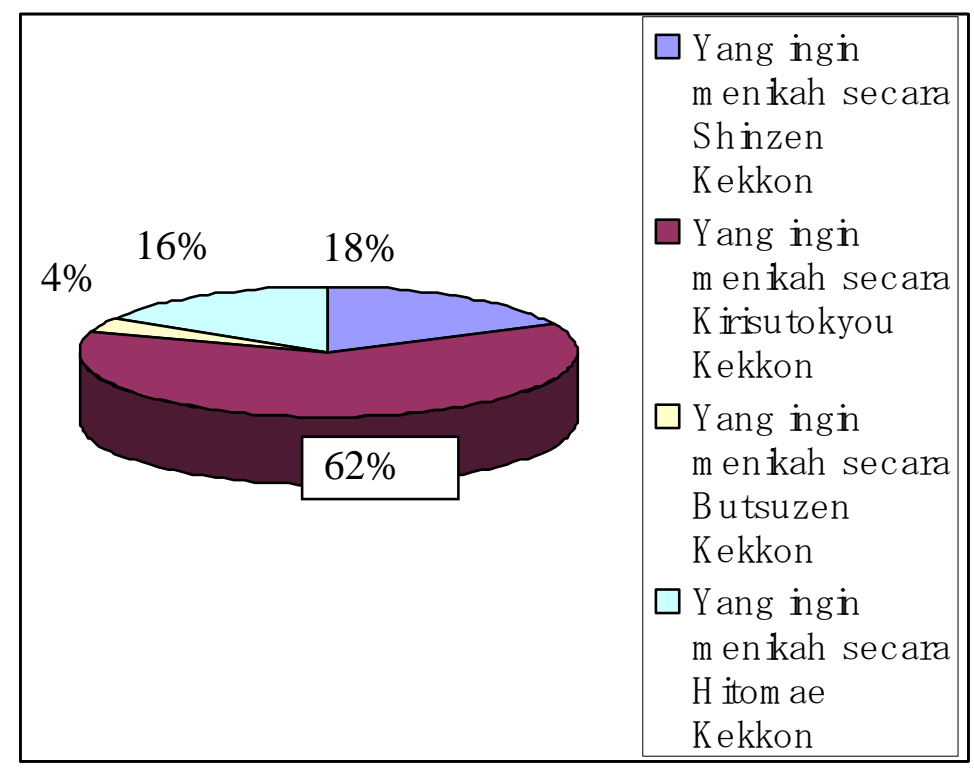

Alasan yang mereka utarakan sangat beragam atas pilihan jenis upacara perkawinan yang mereka ingin lakukan. Berikut ini saya akan jabarkan alasan mereka masing-masing terhadap pilihan jenis perkawinan 62\% yang memilih upacara perkawinan berdasarkan agama Kristen (Kirisutokyo kekkonshiki) beralasan sebagai berikut:

a. Bahwa perkawinan jenis ini sudah merupakan perkawinan Internasional (64, 5\% / 20 orang)

b. Sudah dikenal di sebagian besar belahan dunia ini dan lebih bergengsi, karena itulah banyak orang Jepang yang melakukan perekawinan di gereja ataupun kapel walaupun mereka bukan penganut agama Kristen (19, 35 \% / 6 0rang).

c. Perkawinan ini lebih familiar di kehidupan mereka sehari-hari, karena maraknya budaya Barat. (16, $12 \%$ / 5 orang)

Dalam memilih upacara perkawinan orang Jepang ternyata banyak yang memilih cara menikah ala barat, lengkap dengan upacara keagamaan secara Kristiani, meskipun mereka sendiri bukanlah penganut agama tersebut. Agama Kristen sendiri masuk ke Jepang pada tahun 1549 yang dibawa oleh missionaris Jesuit Santo Fransisikus Xaverius. Dimasa itu banyak timbulnya berbagai percekcokan dan kerusuhan dimana-mana, oleh sebab itu agama Kristen disambut hangat oleh masyarakat Jepang yang memerlukan lambang kerohanian baru agar mereka bisa keluar dari berbagai masalah yang terjadi dalam tahun-tahun tersebut. Selain itu ada juga yang mengharapkan dengan masuknya budaya Barat maka mereka bisa mendapatkan berbagai teknologi-teknologi Barat yang sebelumnya mereka belum lihat, seperti senjata api. Pada akhir abad ke-16 sampai pertengahan abad ke-19, agama Kristen sempat dilarang oleh pemerintahan Bakufu karena dianggap subversif terhadap ketertiban yang baru dicapai.

Shigeyoshi Muramaki (1980:34-35), mengatakan bahwa ajaran Katolik telah masuk Korea dan Pulau Ryuukyu sekitar tahun 1830. Tidak lama kemudian pendeta Petitjean tiba di Jepang yaitu 
sekitar tahun 1829 dan membawa misi kerjasama dalam administrasi Asia Perancis koloni, misinya adalah menyebarkan ajaran Katolik ke Jepang. Sebelumnya misi ini sudah berhasil diterapkan di negara Indocina. Pada tahun 1858 setelah perjanjian komersial antara Perancis dan Jepang, P.S Girard (pendeta dari duta besar Perancis di Jepang) datang ke Jepang dengan menggunakan kapal asing yang sudah diperbolehkan masuk ke Jepang. Kedatangannya tidak lain untuk menyebarkan ajaran agama Katolik ke berbagai wilayah di Jepang.

Empat tahun kemudian atau tepatnya tahun 1862 Girard mendirikan kapel Katolik di Yokohama untuk pertamakalinya di Jepang setelah dua setengah abad yang lalu semua gereja di Jepang dihancurkan oleh pemerintahan Bakufu. Saat itu kapel tersebut atau yasodera ( sebutan orang Jepang saat itu ) hanya dipakai oleh orang asing saja. Dengan kehadiran kapel tersebut orang Jepang sempat terkejut karena merasa takjub setelah melihat Kotbah yang ada di dalam kapel tersebut.

Selanjutnya pada tahun 1865 Petitjean juga mendirikan kapel di Nagasaki untuk warga Perancis. Kapel tersebut bercorak Eropa dengan bangunan yang penuh kaca dan menara yang sangat tinggi. Masyarakat Jepang saat itu menyebut kapel itu dengan sebutan "kuil Perancis", dan mulai tertarik untuk masuk ke dalam kapel tersebut dan mendalami ajaran agama Katolik tersebut. Petitjean menyadari bahwa walaupun agama Kristen di Jepang telah mati sejak abad ke 16, tapi masyarakat Jepang pada umumnya masih merasa bahwa agama Kristen ataupun Katolik merupakan suatu pencerahan kehidupan bagi mereka. Dan pada akhirnya penganut agama Kristen maupun Katolik mencapai 1,7 umat.

Di luar pengaruh agama Kristen, masyarakat Jepang pada saat itu juga mendapat pengaruh budaya asing karena banyaknya orang asing datang ke Jepang setelah dibukanya pelabuhan Jepang untuk kapal-kapal asing. Semenjak itu modernisasi di bidang kebudayaan berturut-turut dilaksanakan secara bertahap. Dimulai pada tahun 1872 (Meiji ke-5), pemerintah Jepang menetapkan sistem pendidikan, sehingga bagi orang Jepang mudah mempunyai pekerjaan dan status apapun bisa mengikuti pendidikan.

Karena asyik dengan budaya luar, yang bersifat budaya pop, dan mempunyai ciri praktis dan cepat, orang muda Jepang kurang mempelajari budaya mereka sendiri dan mengaplikasikannya ke kehidupan mereka sehari-hari. Pasangan muda biasanya tidak nyaman dengan budaya Jepang yang mempengaruhi tata cara upacara perkawinan Jepang yang mereka anggap sangat rumit. Untuk persiapan dan pelaksanaan ritual sebuah upacara perkawinan sangat membutuhkan waktu yang sangat lama dan prosedur yang berbelit-belit dan biaya yang tinggi. Orang muda sendiri memang identik dengan budaya pop yang mempunyai sifat sering berubah sesuai dengan zamannya (Bestor et al: 1989).

Orang muda Jepang mempunyai sifat dinamik dan senang akan perubahan yang baru. Sifat ini pulalah yang mempengaruhi mengapa orang muda Jepang memilih perkawinan secara Kristen, yang dianggap lebih praktis dan tidak banyak memakan biaya.

Alasan yang tidak kalah menarik adalah 90\% (28 orang) dari responden perempuan Jepang yang menjawab ingin menikah secara kristiani (Kirisuto Kekkon) berangan-angan bahwa kelak kalau menikah mereka ingin menggunakan wedding dress yang berwarna putih dan sangat panjang.

Sedangkan alasan para responden yang memilih menikah secara Shinzen Kekkon adalah, sifat nasionalisme yang tinggi sebagai warga negara Jepang, jadi dalam melakukan suatu hal apapun harus sesuai dengan budaya Jepang. Mereka menganggap bahwa orang Jepang yang tidak melakukan perkawinan berdasarkan Shinzen kekkon ini, dianggap rasa nasionalisme mereka terhadap bangsa sendiri sudah luntur. 
Alasan berikut ini juga tidak kalah menarikanya adalah walaupun responden itu beragama Kristen, dia ingin menikah dengan melakukan Shinzen kekkon, karena dia ingin menikah dengan memakai pakaian tadisi kimono. Baginya dengan memakai kimono pada saat upacara perkawinan di samping karena merupakan pakaian tradisional Jepang, juga mempunyai makna tersendiri. Sejak Restorasi Meiji pada tahun 1868, dan khususnya selama Perang Dunia II, Shinto diangkat oleh penguasa menjadi agama negara. Berdasarkan undang-undang dasar setelah perang, Shinto telah memberi dukungan resmi ataupun hal khusus dalam peran pada upacara penting dan upacara perkawinan bagi kehidupan orang Jepang (Murakami, 1980).

Alasan lain para responden yang memilih perkawinan Shinzen Kekkon memberikan alasan sebagai berikut:

a. Ingin mengadakan jenis upacara perkawinan yang lain dari yang lain dan yang jarang dilakukan oleh kebanyakan orang (shinzen kekkonshiki), yang memberikan alasan ini sebanyak 44\% ( 4 orang )

b. Alasan yg terakhir adalah supaya ingin merasakan bagaimana upacara pernikahan yang selalu dipilih oleh keluarga Kaisar Jepang serta orang- orang terpandang lainnya, dengan kata lain mereka yang melakukan jenis perkawinan ini akan menaikan prestise mereka di hadapan orang lain karena jenis perkawinan ini termasuk upacara perkawinan yang mahal. Yang memberikan alasan ini adalah 56\% / (5 orang)

Sisa responden yaitu 4\% (2 orang) memilih perkawinan berdasarkan agama Budha, Butsuzen kekkonshiki. Alasan responden pertama memilih perkawinan secara Budha karena keluagra dekat responden adalah seorang biksu Budha dan mereka juga merupakan penganut agama Budha yang sangat taat. Sehingga menikah dengan cara Budha merupakan suatu keharusan. Responden kedua beralasan karena orang tuanya beragama Budha dan kebetulan dia sebagai choonan atau anak pertama di keluarga itu jadi dia tidak mau menjadi anak yang durhaka dengan menikah dengan cara selain agama Budha.

\section{PENUTUP}

Masyarakat Jepang yang dikenal sebagai bangsa yang sangat mempertahankan nilai budaya dan tradisi ternyata setelah masuknya budaya asing khususnya budaya Barat nilai-nilai budaya dan cara pemikiran orang Jepang mengalami perubahan. Hal tersebut dibuktikan dengan mulai hilangnya tradisi perkawinan cara Shinto yang dikenal dengan shinzen kekkonshiki yang merupakan ciri khas sistem perkawinan yang ada di Jepang sudah jarang dilakukan.

Masuknya budaya asing yang membawa berbagai aspek terhadap masyarakat Jepang, salah satunya adalah agama, membuat masyarakat Jepang semakin mengenal berbagai agama. Agama yang merupakan dasar dari upacara perkawinan, membuat tata cara upacara pernikahan semakin banyak. Saat ini upacara perkawinan di Jepang dapat dibedakan menjadi empat macam yaitu, Kirisutokyoo kekkonshiki (キリスト教結婚式 ) yaitu upacara perkawinan berdasarkan agama Kristen. Butsuzen kekkonshiki ( 仏前結婚式 ) upacara perkawinan berdasarakan agama Budha, Hitomae kekkonshiki ( 人前結婚式 ) upacara perkawinan dihadapan orang. Dan upacara perkawinan Shinto yaitu shinzen kekkoshiki ( 神前結婚式 ).

Pada zaman Edo, tata cara perkawinan yang dilakukan merupakan perkawinan yang tidak dihormati bagi orang Eropa. Hal itu karena bagi orang Eropa, semua perkawinan ada tanda persetujuan dan hubungannya dengan agama dan Tuhan sedangkan di Jepang perkawinan cukup disetujui oleh dua belah pihak yang akan menikah saja. Oleh karena itulah, orang Jepang yang selalu menjunjung tinggi pada orang Barat juga mau membuktikan bahwa tatacara perkawinan mereka juga ada kaitannya 
dengan Tuhan, maka dari saat itulah Shinto menjadi paduan tata cara perkawinannya. Shinto adalah kepercayaan asli Jepang dan sejak zaman kuno Shinto telah menjadi bagian hidup dalam masyarakat Jepang dan menjadi bagian dari pandangan hidup orang Jepang. Atas dasar pemikiran tersebut shinzen kekkonshiki menjadi sistem pernikahan pertama yang menggunakan ajaran Shinto sebagai dasar tata cara perkawinannya, yang diadakan pertamakali oleh Kaisar Taisho.

Masuknya budaya Barat mempengaruhi berbagai aspek kehidupan di Jepang dalam segala bidang. Dan budaya tersebut diakulturasikan sehingga menjadi budaya baru dalam masyarakat Jepang. Akulturasi budaya yang paling istimewa dalam sistem sosial Jepang adalah westernisasi. Westrenisasi yang mengacu pada modernisasi dilakukan oleh pemerintah Jepang karena pemerintah Jepang ingin membuat negaranya sejajar dengan negara Barat. Pemerintah menetapkan sistem pendidikan yang bisa diikuti oleh status apapun. Dalam melakukan pembaharuan dalam bidang pendidikan pemerintah Jepang mengirim orang untuk belajar di negara Barat. Teknologi Barat dan budayanya pun akhirnya menjadi bagian dari masyarakat Jepang. Perkawinan agama Kristen yang diselenggarakan di gereja dengan pemimpin upacara seorang pendeta atau pastor menjadi salah satu tata cara perkawinan yang populer oleh masyarakat Jepang sejak tahun 1920.

Sistem pendidikan di luar negeri juga mempengaruhi keberadaan shinzen kekkonshiki yang merupakan sistem perkawinan khas bangsa Jepang yang mulai hilang. Dalam penulisan skripsi ini yang menggunakan metode penyebaran angket melalui e-mail yang disebar kepada orang Jepang yang tinggal didaerah Kansai. Dari angket ini membuktikan bahwa pengaruh budaya Barat menyebabkan shinzen kekkonshiki sudah jarang digunakan oleh orang Jepang yang dibuktikan dari jawaban-jawaban orang Jepang yang belum menikah.

Dari 50 sampel yang penulis tanyakan melalui angket yang disebarkan sebelumnya hanya 09 orang yang mau memilih jenis perkawinan shinzen kekkonshiki. Empat puluh satu orang yang lain tidak memilih perkawinan shinzen kekkonshiki. Dari 41 orang yang tidak memilih shinzen kekkonshiki itu mengatakan bahwa jenis perkawinan tersebut memerlukan prosedur yang sangat lama. Di samping itu, juga tempat penyelenggaraan jenis perkawinan ini tidak begitu banyak dan walaupun ada tempat upacaranya, juga tidak begitu besar sehingga kedua mempelai tidak bisa mengundang semua keluarga dan kerabatnya. Selanjutnya ada yang mengatakan bahwa sangat sedikit sumber informasi yang menjelasakan jenis perkawinan ini dan prosedur-prosedur apa saja yang mesti dilakukan oleh kedua calon mempelai tersebut kalau mereka ingin melakukan jenis perkawinan ini. Dan bahkan sebagian anak muda Jepang tidak tahu, tidak pernah melihat langsung jalannya upacara perkawinan shinzen kekkonshiki. Di lain pihak semakin gencarnya promosi yang digencarkan oleh perusahaan travel dan pariwisata yang mengeluarakan paket wisata hitomae kekkon shiki ( 人前結婚式) dan honeymoon yang menjadi satu. Karena biayanya murah, tidak memerlukan prosedur bertele-tele dan singkat, maka kebanyakan orang Jepang yang sangat sibuk dalam kehidupan sehari-harinya dan sangat mengahargai waktu lebih condong memilih jenis perkawinan ini karena tidak merepotkannya dan sudah termasuk perjalanan wisata demi mengurangi stress dari rutinas sehari-hari.

Melalui angket tersebut juga, orang Jepang banyak yang memilih perkawinan ala barat yaitu perkawinan agama Kristen. Alasan dari responden menggunakan tata cara perkawinan Kristen dikarenakan untuk melakukan pernikahan ini tidak memerlukan biaya yang mahal, tidak membuang banyak waktu mereka, dan tidak banyak aturan-aturan dalam melakukan upacara ini. Terakhir yang mempengaruhi sudah jarangnya pelaksanaan shinzen kekkonshiki pada saat sekarang yaitu sistem pendidikan. Sistem yang sudah modern membuat orang Jepang banyak yang belajar di luar negeri. Dari hal tersebut setiap orang harus menguasai bahasa asing dan budaya setempat. Budaya yang dipelajari membuat cara pikir masyarakat Jepang mengalami perubahan. Pengaruh kebudayaan yang telah tercampur oleh kebudayaan Barat menyebabkan upacara perkawinan orang Jepang khususnya anak muda Jepang sudah mengikuti perkawinan gaya Barat. 
Dari uraian-uraian yang telah dikemukakan penulis melalui data-data berupa buku panduan dari pendapat-pendapat para ahli dalam bidang ini, hasil angket yang disebarkan kepada orang Jepang, penulis mengambil simpulan bahwa memang benar tradisi perkawinan shinzen kekkonshiki mulai hilang keberadaannya diakibatkan masuknya budaya Barat, sistem pendidikan, dan agama Kristen yang telah merubah cara pandang dan pemikiran masyarakat Jepang.

\section{DAFTAR PUSTAKA}

Bestor, Theodore C. 1989. Handbook of Japanese Popular Culture edited by Richard Gid Powers and Hidetoshi Kato. London: Greenwood Press.

Baker, Chris. 2004. Cultural Studies: Teori \& Praktik.Yogyakarta: Kreasi Wacana Yogyakarta

Fukutake, Tadashi. 1988. Masyarakat Jepang dewasa ini. Jakarta: PT Gramedia dan Yayasan Karti Sarana

Naka, Hisao. 1980. Kaum muda Jepang dalam masa perubahan. Yogyakarta: Gadjah Mada University Press.

Reichaver, Edwin. O et al.1988. The Japanese Today. Harvard University: Belknap Press.

Storey, John. 2003. Teori budaya dan budaya pop: Memetakan Lanskap Konsetual Cultural Studies. Yogyakarta: CV. Qalam. 